compounds, and so could provide clues about early life on Earth. Little is known about them because scientists are rarely able to study them at the temperatures and pressures at which they naturally live.

"There are many questions that need to be answered," says John Parkes, a geomicrobiologist at the University of Bristol, UK. "A deep mine will be very valuable."

Both Republicans and Democrats had originally been keen to back the project in order to win support for their candidates contesting the South Dakota seat in this November's Senate elections.

But with political enthusiasm lessening as attention turns to Iraq, a dispute between the NSF, which is expected to fund and run the lab, and Barrick Gold Corporation, Homestake's owners, could scupper the plans of physicists and geologists. The NSF is adamant that the proposal must undergo peer review, but in a public letter last month, Barrick's vicepresident Patrick Garver stated that the process would take too long. "It appears to us that a final determination is unlikely to be finalized for several years," he said.

Moreover, Congress is reluctant to agree to Barrick's demand that the NSF assumes environmental liability for the lab before the takeover. If an agreement cannot be reached soon, Barrick says it will allow the mine to flood.

Nonetheless, scientists at the Washington conference remained hopeful that Homestake, or perhaps another site, will become a reality. They say they appreciated the chance to discuss one another's fields, and look forward to the possibility of sharing a lab. "To have these kinds of conversations around the lunch table would just be fantastic," says Onstott.

\title{
BSE in human tissue fires debate on patient disclosure
}

Erika Check

For the first time, a tissue sample removed in Britain during routine surgery has tested positive for the human form of bovine spongiform encephalopathy (BSE). The find has reopened the debate over whether people found to be incubating the fatal neurodegenerative disease should be informed.

Last week, researchers announced that they had turned up one positive sample of the misshapen protein, or prion, thought to cause variant Creutzfeldt-Jakob disease (vCJD), among 8,318 tonsils and appendices removed from patients in the late 1990 s (D. A. Hilton et al. Br. Med. J. 325, 633-634; 2002). Earlier data from 3,000 samples had returned negative results (see Nature 405, 7; 2000).

From this, the researchers estimate that about 120 out of every million Britons might eventually develop vCJD, thought to be the result of eating meat products from cattle infected with BSE. That number falls within previous estimates, based on epidemiological modelling, of several thousand cases. But, given that the new calculations are based on just one case, the margin of error remains large. "We're not going to jump to any conclusions," says David Hilton of the Derriford Hospital in Plymouth, who led the team.

Hilton says that testing of further samples under the existing study, in collaboration with the CJD Surveillance Centre in Edinburgh, will continue through next year. And the British government's chief medical officer, Liam Donaldson, adds that a larger tissuescreening study is planned, which may further

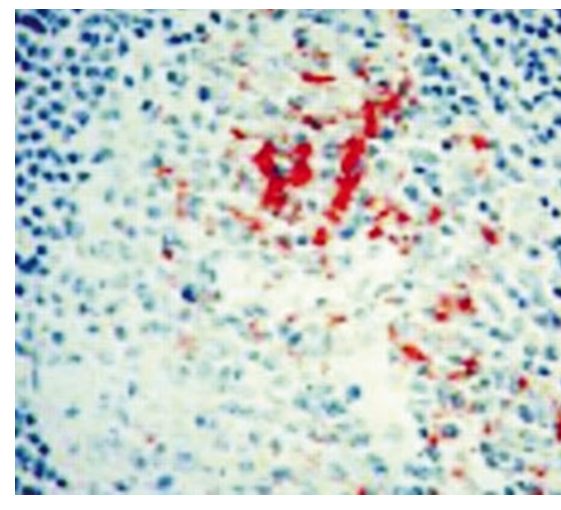

Tell-tale tinge: a red colour betrays the presence of BSE prion in this human appendix sample.

clarify the disease's eventual prevalence.

Meanwhile, Swiss scientists have begun their own screen of tissues from surgery and autopsies. Adriano Aguzzi, a neuropathologist at the University Hospital in Zurich, says doctors will examine thousands of samples over the next decade or so. But whereas the UK survey is anonymous, so that patients who test positive cannot be notified, the Swiss survey will retain patients' details.

"We think the science in the prion field is advancing very quickly, and it's not unlikely that in three or five years' time there will be a way to block the prion from causing disease," says Aguzzi. If therapy becomes available, Swiss test results will be made available; they will also be disclosed to specific patients who request them even in the absence of a cure.

\section{Nanoscale etchings let art lovers read the small print}

\section{Carina Dennis, Sydney}

For Stephanie Valentin, an artist at Sydney's College of Fine Arts, it was a new world to explore. Paul Munroe, a materials scientist at the University of New South Wales in Sydney, found it a rare opportunity to apply a tool commonly used for studying electronic circuits to a biological specimen. The result - a series of micrometre-high words carved into grains of pollen - went on display in Sydney's Stills Gallery on 11 September.

Valentin approached Munroe in her quest to find a method for writing on pollen. He suggested using a focused ion beam miller: a device usually used to etch the surface of electronic circuits. With Munroe's help, Valentin used a narrow beam of gallium ions to carve words on

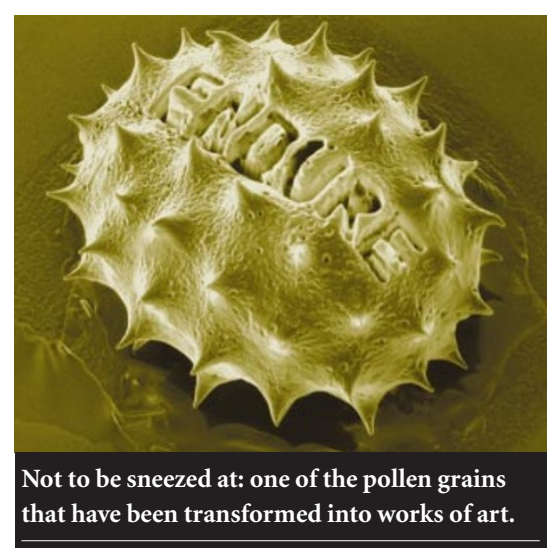

pollen grains with a diameter of around 20 micrometres.

The project has useful scientific spin- offs, as other researchers are interested in using focused ion beam millers to study biological samples. "What is notable is that they were able to use it to etch pollen without destroying it in the process, and with a very high degree of precision and control," says Ian Williams of the Australian National University (ANU) in Canberra, who uses ion beams to analyse geological samples.

"Not much work has been done on biological materials," says Sally Stowe, also at ANU. Stowe plans to use focused ion beams to scrutinize the interface between hard and soft materials, such as titanium implants in bone. The ion beam should allow her to carefully cut away layers of the sample without damaging it. "It's a nanoscale Swiss Army knife," she says. 